\title{
FEV1 and FVC repeatability goals when performing spirometry
}

\author{
Paul Enright \\ Professor of Medicine, \\ The University of Arizona, \\ Tucson, \\ Arizona, \\ USA \\ Correspondence: \\ E-Mail: lungguy@aol.com
}

5th May 2010

(c) 2010 Primary Care Respiratory Society UK. All rights reserved

\section{Dear Sir,}

I applaud the Spirometry standards document by Levy et al. published recently in this journal. ${ }^{1}$ I note the recommendation in the section on 'Conducting the spirometry test' that the standard for repeatability of $\mathrm{FEV}_{1}$ and FVC should be $150 \mathrm{ml}$. This is correct.

The ATS/ERS 2005 spirometry quality goals ${ }^{2}$ were based on two very large studies, one in school-aged children ${ }^{3}$ and one in adult patients. ${ }^{4}$ The FEV $_{1}$ and FVC repeatability goals of $150 \mathrm{ml}$ were set so that highly experienced technologists can meet them $90 \%$ of the time. Some organisations, ${ }^{5}$ some large studies, ${ }^{6.8}$ and some spirometers, assign a spirometry test session quality grade from $A$ to $F$, where three acceptable manoeuvres with $\mathrm{FVC}$ repeatability of $100 \mathrm{ml}$ or better gets an A grade, FVC repeatability of $150-100 \mathrm{ml}$ gets a B grade, and FVC repeatability of $200-150 \mathrm{ml}$ gets a $C$ grade. When the setting demands optimal quality (such as in research studies using change in $\mathrm{FEV}_{1}$ or $\mathrm{FVC}$ as the primary outcome measure), technologists strive for an A or B grade, and some succeed more than $90 \%$ of the time. ${ }^{9}$ Not surprisingly, the within-test session $\mathrm{FEV}_{1}$ repeatability is an independent predictor of visit-tovisit $\mathrm{FEV}_{1}$ reproducibility. ${ }^{8}$

In some settings, optimal quality is not necessary. For example, when using spirometry to detect moderate to severe lung disease (using a single cross-sectional test), it makes no difference to the individual subject (or patient) whether their $\mathrm{FEV}_{1}$ is $95 \%$ predicted or $115 \%$ predicted. ${ }^{6,10}$ No study has yet been done to determine how bad the quality of spirometry can be without changing the interpretation or medical decisions based on the results. The mantra of pulmonary function experts remains: minimise misclassification.

\section{Conflict of interest declaration}

The author has no conflicts of interest on this topic.

\section{References}

1. Levy M, Quanjer PH, Booker R, Cooper BG, Holmes S, Small I. Diagnostic Spirometry in Primary Care: Proposed standards for general practice compliant with American Thoracic Society and European Respiratory Society recommendations. Prim Care Resp J 2009;18(3):130-47. http://dx.doi.org/10.4104/pcrj.2009.00054

2. Miller MR, Hankinson J, Brusasco V, et al. Standardisation of spirometry. Eur Respir J 2005;26(2):319-38. http://dx.doi.org/10.1183/09031936.05.00034805

3. Enright PL, Linn WS, Avol EL, Margolis H, Gong H, Peters JM. Spirometry quality in children and adolescents: experience in a large field study. Chest 2000;118:665-71. http://dx.doi.org/10.1378/chest.118.3.665

4. Enright PL, Beck KC, Sherrill DL. Repeatability of spirometry in 18,000 adult patients. Am J Respir Crit Care Med 2004;169(2):235-8. http://dx.doi.org/10.1164/rccm.200204-3470C

5. Ferguson G, Enright PL, Buist AS, Higgins M. Office spirometry for lung health assessment in adults. An consensus statement from the National Lung Health Education Program. Chest 2000;117:1146-6. http://dx.doi.org/10.1378/chest.117.4.1146

6. Vollmer WM, Gíslason T, Burney P, et al. Comparison of spirometry criteria for the diagnosis of COPD: results from the BOLD study. Eur Respir J 2009;34(3):588-97. http://dx.doi.org/10.1183/09031936.00164608

7. Malmstrom K, Peszek I, Botto A, Lu S, Enright PL, Reiss TF. Centralized spirometry quality control improves efficiency of asthma clinical trials. Controlled Clinical Trials 2002;23:143-56. http://dx.doi.org/10.1016/S0197-2456(01)00197-0

8. Enright PL, Connett JE, Kanner RE, Johnson LR, Lee WW. Spirometry in the Lung Health Study: 2. Determinants of short-term intra-individual FEV1 variability. J Respir Crit Care Med 1995;151:406-11.

9. Enright PL, Skloot GS, Cox-Ganser JM, Udasin IG, Herbert R. Quality of spirometry performed by 13,599 participants in the World Trade Center Worker and Volunteer Medical Screening Program. Respir Care 2010;55(3):303-09.

10. Enright P. Over $90 \%$ of smokers don't need an expensive inhaler. Prove it by using a pocket spirometer. The European Respiratory Society 2010 Buyers Guide to Respiratory Care Products. http://www.ersbuyersguide.org/uploads/Document/fa/WEB_CHEMIN_5040_1252514654.pdf 